\title{
Legume Biofortification and the Role of Plant Growth-Promoting Bacteria in a Sustainable Agricultural Era
}

\author{
Mariana Roriz ${ }^{1}{ }^{(}$, Susana M. P. Carvalho ${ }^{1,2}{ }^{\mathbb{D}}$, Paula M. L. Castro ${ }^{1}$ and \\ Marta W. Vasconcelos $1, * \mathbb{D}$ \\ 1 CBQF-Centro de Biotecnologia e Química Fina-Laboratório Associado, Universidade Católica Portuguesa, \\ Escola Superior de Biotecnologia, Rua Diogo Botelho 1327, 4169-005 Porto, Portugal; \\ mroriz@porto.ucp.pt (M.R.); susana.carvalho@fc.up.pt (S.M.P.C.); plcastro@porto.ucp.pt (P.M.L.C.) \\ 2 GreenUPorto-Research Centre on Sustainable Agrifood Production \& DGAOT, Faculty of Sciences, \\ University of Porto, Campus de Vairão, Rua da Agrária 747, 4485-646 Vairão, Portugal \\ * Correspondence: mvasconcelos@porto.ucp.pt
}

Received: 3 March 2020; Accepted: 18 March 2020; Published: 22 March 2020

\begin{abstract}
World population growth, together with climate changes and increased hidden hunger, bring an urgent need for finding sustainable and eco-friendly agricultural approaches to improve crop yield and nutritional value. The existing methodologies for enhancing the concentration of bioavailable micronutrients in edible crop tissues (i.e., biofortification), including some agronomic strategies, conventional plant breeding, and genetic engineering, have not always been successful. In recent years, the use of plant growth-promoting bacteria (PGPB) has been suggested as a promising approach for the biofortification of important crops, including legumes. Legumes have many beneficial health effects, namely, improved immunological, metabolic and hormonal regulation, anticarcinogenic and anti-inflammatory effects, and decreased risk of cardiovascular and obesity-related diseases. These crops also play a key role in the environment through symbiotic nitrogen $(\mathrm{N})$ fixation, reducing the need for $\mathrm{N}$ fertilizers, reducing $\mathrm{CO}_{2}$ emissions, improving soil composition, and increasing plant resistance to pests and diseases. PGPB act by a series of direct and indirect mechanisms to potentially improve crop yields and nutrition. This review will focus on the: (i) importance of legumes in the accomplishment of United Nations Sustainable Development Goals for production systems; (ii) understanding the role of PGPB in plant nutrition; (iii) iron biofortification of legumes with PGPB, which is an interesting case study of a green technology for sustainable plant-food production improving nutrition and promoting sustainable agriculture.
\end{abstract}

Keywords: Biofortification; iron; legumes; malnutrition; plant growth-promoting bacteria; sustainable agriculture

\section{Introduction}

The world population has considerably increased in the past 10 years and is expected to reach around 9.5 billion by 2050 [1], with developing countries accounting for much of this increase [2], and this represents a huge challenge for agricultural sustainability [3]. The population growth is increasing the pressure on arable land and natural resources, which together with the environmental stresses associated with climate change, is severely affecting plant growth, productivity, and nutritional value. Furthermore, the excessive use of fertilizers and pesticides has a great impact on the environment, causing soil and water deterioration [4-7]. All these issues are reflected in human health, with increased malnutrition problems, not only in developing economies but also in developed countries where, although food is available, its nutritional value is poor [8]. Nowadays, consumers in developed countries 
are increasingly concerned with the chemical residues in products, demanding more sustainable agricultural practices focusing on safer products, free of chemical residues. It is urgent to act in a sustainable manner to face the current societal challenges to guarantee the production of foods with high nutritional content combined with low environmental foodprint.

Biofortification appears to be a promising strategy to fulfill the constraints previously described. It is defined, according to the World Health Organization (WHO) as, "the process by which the nutritional quality of food crops is improved through agronomic practices, conventional plant breeding, or modern biotechnology" [9]. Within this context, the agronomical practices aim to improve mineral uptake, either through fertilizer application or increased nutrient solubilization and mobilization in the soil [10]. The other two methodologies focus on the improvement of micronutrient contents of edible plant tissues and their bioavailability for humans [11].

The first steps in biofortification programs were made when rice genetically modified with beta-carotene, golden rice, appeared [12]. However, golden rice is not yet commercialized as genetically modified crops are not very well accepted by several societies [13]. The HarvestPlus program is one of the most significant, systematic, and symbolic breeding programs. It is a large biofortification platform launched in 2004 to reduce micronutrient malnutrition in Asia and Africa. The program has focused on seven staple food crops (rice, beans, cassava, maize, sweet potatoes, pearl millet, and wheat) and targeted three major nutrients (Fe, Zn, and vitamin A) [11].

Carvalho and Vasconcelos [11] and Garg et al. [14] have reviewed these three biofortification methodologies and performed an analysis of their strengths, weaknesses, opportunities, and threats. They concluded that the success of the biofortification programs is strongly dependent on the farmers and public acceptance as well as on political support, which will dictate their cost/benefit. Regarding future scientific challenges, one of the major issues in this field is the incomplete understanding of the rate-limiting steps that are involved in translocating minerals to seeds, and further studies in this area are required. Also, the assurance that careful and systematic safety analyses of these products will be conducted before they become readily available to consumers is of extreme importance. Metabolomic studies will provide added value for food safety assessment programs, allied with currently used analytical methods.

There is still a long way to go before biofortification is strongly implemented and sustained. Some efforts have already been made in this direction to integrate biofortification into global standards and guidelines by the Codex Alimentarius, the food standards-setting agency, together with WHO, the Food and Agriculture Organization of the United Nations (FAO), and the Sanitary and Phytosanitary Agreement (SPS) of the World Trade Organization (WTO) [15].

The utilization of biofertilizers-_products that contain living microorganisms, which exert direct and indirect beneficial effects on plant growth and crop yield through different mechanisms"-[16] is an important environmentally friendly alternative to the strategies described above. Many studies show the possible roles of rhizospheric and endophytic microbes in crop biofortification [17]. More recently, several studies have shown that plant growth-promoting bacteria (PGPB), directly or indirectly, enhance plant growth, crop nutrition, and tolerance to abiotic stress [18-26] through several mechanisms. The utilization of these bacteria has been suggested as a promising green technology for increasing the nutrient content of crops from a biofortification perspective.

Legumes are a good target for increasing the nutritional value of foods, particularly in developing countries where cereals and legumes are the major food source. The association of legumes with their natural colonizing microorganisms appears to be a powerful combination for a sustainable and eco-friendly approach to cope with climate change effects on crops and to improve plant nutrition. Apart from their rich nutritional value, legumes also play an important ecological role [27].

In this review, we will focus on the: (i) importance of legumes in the accomplishment of United Nations Sustainable Goals for production systems; (ii) understanding the role of PGPB in plant nutrition; (iii) iron biofortification of legumes with PGPB, which is an interesting case study of a green technology for sustainable plant-food production improving nutrition and promoting sustainable agriculture. 


\section{The Importance of Legumes in the Accomplishment of the Sustainable Development Goals}

The world is facing a time of important agricultural losses in terms of productivity and nutritional crop value due to the well-known climate change phenomenon, which includes global warming and more frequent occurrence of severe weather events (heavy rains and drought). As a consequence, more than two billion people suffer from malnutrition problems due to food shortage (acute hunger) or insufficient intake of essential micronutrients (hidden hunger) [28]. Deficiency in the main micronutrients, zinc ( $\mathrm{Zn}$ ), iron (Fe), and selenium (Se), has a great impact on human health. Zn deficiency reflects in inappropriate physical growth, wound healing, and skeletal development, and is associated with augmented risk of infection. Fe deficiency is associated with cases of anemia and fatigue, also affecting the immune system. Se deficiency can affect male fertility, impair the immune system, increase infection vulnerability, cause mental slowing, and result in cases of hypothyroidism [29].

There has been a growing demand for sustainable agricultural practices to achieve food security in this milieu, and so-called "climate-smart agriculture", which aims at using agricultural approaches that are "resistant" to climate change effects and are environment-friendly, has emerged [28]. In 2015, the United Nations (UN) outlined 17 goals in a "Sustainable Development Goals Project", with the second being to "end hunger, achieve food security and improve nutrition, and promote sustainable agriculture" [30]. This problem is not only affecting human health and the environment but also has a great impact on the economy, representing the most important socio-economic challenge of the century [31]. Amongst the strategies proposed by the UN to improve food nutrition and fight malnutrition are increases in dietary diversity, food supplementation, food fortification, and biofortification [32]. Fortification of foods during processing appears to be a promising way to improve the nutrient composition of meals; however, this strategy is not accessible to all populations [32].

Biofortification appears to be a feasible approach to improve the nutritional value of foods, with a special significance for the most deprived populations [11,33]. Plants are an important source of essential minerals and vitamins, and in developing countries grains and legumes are the primary, and often the only, source of food [34]. In particular, legumes are excellent sources of amino acids, nutrients, and vitamins, being similar to or even better than cereals [32]. Their inclusion in the human diet has been reported as having many potential health benefits (Table 1). The presence of some particular compounds in legumes, such as soluble fibers, antioxidants, flavonoids, etc., seems to be associated with reduced cases of diabetes, cardiovascular diseases, and some types of cancers, among others $[35,36]$. However, these types of studies are still not conclusive as the effect of legume consumption on human health seems to be dependent on the type, amount, and frequency of legume consumption, and they also do not consider the effects of processing [35]. In the environment, legumes are part of the symbiotic $\mathrm{N}$ fixation process, reducing the need for $\mathrm{N}$ fertilizer, decreasing agricultural $\mathrm{CO}_{2}$ emissions, and improving soil composition [37]. The inclusion of legumes in crop rotation systems, besides conferring pest and disease resistance to the succeeding crops [38], can reduce greenhouse gas emissions by up to $25 \%$ [39].

Table 1. Summary of the potential beneficial effects of legume consumption on human health.

\begin{tabular}{lc}
\hline \multicolumn{1}{c}{ Potential Beneficial Health Effects } & References \\
\hline Increased immunological, metabolic, and hormonal regulation & {$[40,41]$} \\
Anticarcinogenic (breast, colorectal, endometrium, and prostate cancers) & {$[42-46]$} \\
and anti-inflammatory effects & \\
Reduced risk of cardiovascular and obesity-related diseases, and & {$[47-50]$} \\
metabolic syndrome & {$[51,52]$} \\
Reduced cholesterol levels & {$[53-55]$} \\
Reduced risk of type 2 diabetes mellitus & {$[56-59]$} \\
Reduced risk of osteoporosis and depression & \\
\hline
\end{tabular}


In 2014, the UN highlighted the importance of legume biofortification programs, making them a good target in the fight against hidden hunger. However, little has been done since then, and the biofortification of legumes remains little explored [32]. Also, 2016 was considered the International Year of the Pulses by the UN. Pulses are legume crops harvested for dry grain production and are the cheapest source of vitamins, micronutrients, and proteins, making them available for everyone and the perfect target for biofortification [60]. Although legume consumption and cultivation have clear benefits, their cultivation has decreased considerably in the last 50 years compared to cereals [38]. One of the reasons for this decrease might be related to their high susceptibility to climate stresses, making them less attractive to farmers. Research working towards improved legume cultivars less susceptible to environmental stresses and with increased yield is therefore essential in a climate change era $[32,61]$.

\section{The Role of PGPB in Legume Nutrition}

Relationships between plants and microorganisms occur, generally, in the rhizosphere and exert beneficial effects on plant nutrition and growth, providing plant resistance and/or protection against biotic and abiotic stresses [62]. Bacteria are the most predominant microorganisms in the soil (95\%) and the greater concentration is found in the rhizosphere [63].

There is a special type of bacteria, the PGPB, which includes either free-living bacteria or those that establish symbiotic relationships with plants in the rhizosphere or via endophytic colonization [64], that are very promising to be used in plant-based biofortification programs for the nutritional improvement of food crops. Plant growth promotion can be achieved by a series of mechanisms that can be direct: $\mathrm{N}$ fixation [65], nutrient (Fe, K, P, and $\mathrm{Zn}$ ) solubilization [66,67], production of several phytohormones (auxins, cytokinins, gibberellins, ethylene, and abscisic acid) [68-70], and production of siderophores and organic acids [19,71,72], or indirect: biocontrol activity through Fe chelation, induced resistance, production of antibiotic, extracellular enzymes and cyanide, and competition for niches in the rhizosphere [73,74]. This promotion involves a series of bacterial components that act in very specific ways. Molecules produced by PGPB are involved in several overlapping mechanisms, influencing plant growth and nutrition and resistance simultaneously. This subject has been reviewed by Premachandra et al. [75] and Rosier et al. [76]. Figure 1 illustrates the main mechanisms underlying plant growth promotion by bacteria, regarding important molecules involved in the different mechanisms.

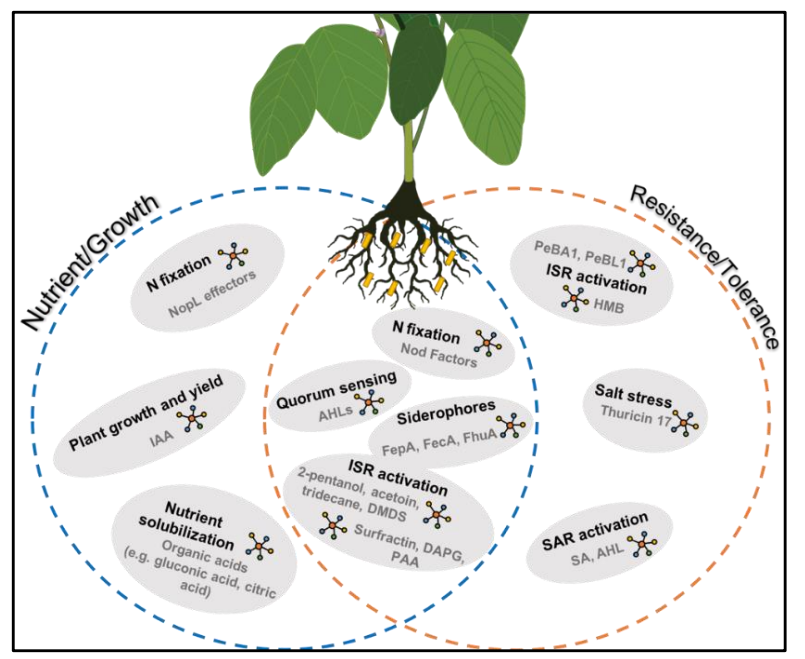

Figure 1. Schematic representation of the main processes and relevant molecules underlying plant growth promotion by bacteria. Abbreviations: $A H L=\mathrm{N}$-acyl homoserine lactone; DAPG = 2,4-diacetylphloroglucinol; DMDS = dimethyl disulfide; $\mathrm{HMB}=3$-hydroxy-5-methoxy benzene methanol; IAA = indole-3-acetic acid; ISR = induced systemic resistance; $\mathrm{N}=$ nitrogen; Nod = nodulation; PAA = phenylacetic acid; SA = salicylic acid. 
Apart from all these mechanisms, PGPB have an important impact on the control of several abiotic stresses and in the bioremediation of polluted soils [77-79].

Focusing on nutrient uptake, in particular, PGPB can act in three different ways: replacing soil nutrients, increasing nutrient availability, and/or improving plant access to nutrients [80].

Several studies have shown the importance of PGPB in the uptake of $\mathrm{B}, \mathrm{Cu}, \mathrm{Fe}, \mathrm{Mn}$, and $\mathrm{Zn}$, through the release of organic acids or the production of siderophores [22]. Furthermore, these microorganisms excrete chelating agents and potentiate redox changes and acidification of the rhizosphere, improving the mobility and availability of plant nutrients $[18,20,81]$. Inoculation with PGPB has had notable success in several crops such as cereals, oil crops, vegetables, and legumes [23-26].

The utilization of PGPB in the improvement of nutrient content in plants is an example of a biofortification strategy that seems to be very promising. Regarding legume biofortification with PGPB, some studies are showing their potential, most of them in chickpeas, mung beans, and soybeans (Table 2). Co-inoculation with Rhizobium galegae bv. orientalis HAMBI 540 and Pseudomonas trivialis $3 R e 27$ increased the nodule numbers and $N$ content of fodder galega plants [82]. Two similar studies in lentils and peas proved that co-inoculation with Rhizobium leguminosarum-PR1 and Pseudomonas sp. NARs1 or Pseudomonas sp. PGERs17 improved nodulation, leghemoglobin, Fe and chlorophyll contents, and $\mathrm{N}$ and $\mathrm{P}$ uptake $[83,84]$. A study in common beans showed that co-inoculation with Pseudomonas sp. LG and Rhizobium phaseoli strain 123 potentiated plant growth and contents of $\mathrm{N}$ and phosphorus (P) [85]. Also, inoculation with two Bacillus aryabhattai strains (MDSR7 and MDSR14) improved the $\mathrm{Zn}$ uptake of soybeans and wheat in $\mathrm{Zn}$-deficient soils [86]. Gopalakrishnan et al. [87] tested seven PGPB in a study with chickpeas and pigeon peas and found Enterobacter ludwigii SRI-229 to be the strain better promoting root and shoot development, nodule formation, crop productivity, and soil nutritional factors, followed by Brevibacterium antiquum SRI-158 and Acinetobacter tandoii SRI-305. In that study, E. ludwigii and A. tandoii strains significantly increased $\mathrm{Fe}, \mathrm{Zn}$, copper $(\mathrm{Cu})$, manganese (Mn), and calcium (Ca) uptake in chickpeas and pigeon peas, respectively. Pantoea dispersa MPJ9 and Pseudomonas putida MPJ6 isolates have been tested for their ability to produce siderophores, showing a great Fe chelating potential under Fe deficient conditions; in this study, the Fe content of mung beans was increased 3.4-fold, protein content 2-fold, and carbohydrate content 1.5-fold after inoculation with the strain of $P$. dispersa [88]. Co-inoculation with Bradyrhizobium japonicum SAY3-7 and Streptomyces griseoflavus $\mathrm{P} 4$ improved N, P, K, Ca, and magnesium $(\mathrm{Mg})$ uptake in soybean plants [89]. A recent study showed that seed coating with Zn solution in combination with a Zn solubilizer PGPB, Enterobacter sp. MN17, improved plant and grain yield and bioavailable Zn, rather than Zn application alone, in chickpeas [90]. Co-inoculation of mung beans with Bacillus aryabhattai S10 and B. subtilis ZM63 proved to be effective in the improvement of plant growth and nutritional composition; N, P, and potassium $(\mathrm{K})$ concentrations were significantly increased in shoots [91]. Also, inoculation of two varieties of chickpeas with five different PGPB (Symbion-K (Frauteria aurantia), Pseudomonas sp. RA6, P. citronellis (PC), Serratia sp. S2, and Serratia marcescens CDP-13) increased macro- and micronutrient concentrations in plants [92]. 
Table 2. Summary of studies showing the potential of some bacterial genera for legume biofortification.

\begin{tabular}{|c|c|c|c|}
\hline Bacterial Genera & Crops & $\begin{array}{l}\text { Contribution to } \\
\text { Biofortification }\end{array}$ & References \\
\hline $\begin{array}{c}\text { Rhizobium galegae bv. orientalis } \\
\text { HAMBI } 540+\text { Pseudomonas trivialis } \\
\text { 3Re } 27\end{array}$ & Fodder galega & Increase $\mathrm{N}$ content & [82] \\
\hline $\begin{array}{l}\text { Rhizobium leguminosarum-PR1 + } \\
\text { Pseudomonas sp. } \\
\text { NARs1/Pseudomonas sp. PGERs17 }\end{array}$ & Lentil, Pea & $\begin{array}{c}\text { Increase } \mathrm{Fe}, \mathrm{N} \text {, and } \mathrm{P} \\
\text { uptake }\end{array}$ & {$[83,84]$} \\
\hline $\begin{array}{c}\text { Pseudomonas sp. LG + Rhizobium } \\
\text { phaseoli strain } 123\end{array}$ & Common bean & Increase $\mathrm{P}$ and $\mathrm{N}$ uptake & [85] \\
\hline $\begin{array}{l}\text { Bacillus aryabhattai MDSR7 and } \\
\text { MDSR14, Enterobacter sp. MN17. }\end{array}$ & $\begin{array}{l}\text { Chickpea, Soybean, } \\
\text { Wheat }\end{array}$ & Increase $\mathrm{Zn}$ uptake & {$[86,90]$} \\
\hline $\begin{array}{l}\text { Acinetobacter tandoii SRI-305, } \\
\text { Enterobacter ludwigii SRI-229 }\end{array}$ & Chickpea, Pigeonpea & $\begin{array}{l}\text { Increase } \mathrm{Fe}, \mathrm{Zn}, \mathrm{Cu}, \mathrm{Mn}, \\
\text { and } \mathrm{Ca} \text { uptake }\end{array}$ & [87] \\
\hline $\begin{array}{l}\text { Bradyrhizobium japonicum SAY3-7 } \\
\text { and Streptomyces griseoflavus P4 }\end{array}$ & Soybean & $\begin{array}{c}\text { Increase } \mathrm{N}, \mathrm{P}, \mathrm{K}, \mathrm{Ca} \text {, and } \\
\mathrm{Mg} \text { uptake }\end{array}$ & [89] \\
\hline $\begin{array}{c}\text { Pantoea dispersa MPJ9, Pseudomonas } \\
\text { putida MPJ6 }\end{array}$ & Mung bean & Increase Fe uptake & [88] \\
\hline $\begin{array}{c}\text { Bacillus aryabhattai } \mathrm{S} 10+\text { B. subtilis } \\
\text { ZM63 }\end{array}$ & Mung bean & $\begin{array}{c}\text { Increase } \mathrm{N}, \mathrm{P} \text {, and } \mathrm{K} \\
\text { uptake }\end{array}$ & [91] \\
\hline $\begin{array}{c}\text { Symbion-K (Frauteria aurantia), } \\
\text { Pseudomonas sp. RA6, P. citronellis } \\
\text { (PC), Serratia sp. S2, Serratia } \\
\text { marcescens CDP-13 }\end{array}$ & Chickpea & $\begin{array}{l}\text { Increase macro- and } \\
\text { micronutrient uptake }\end{array}$ & [92] \\
\hline
\end{tabular}

In recent years, the investigation into the role of PGPB as biofertilizers (BF) for biofortification programs has intensified, although it is still rare. BF, also termed biostimulants, are considered "any substance (of biological origin) or microorganism or their combination applied to plants, seeds, or soil to enhance nutrient uptake efficiency, stress tolerance activation, and crop quality improvement" [93]. Their ability to improve crop quality, productivity, and nutrient uptake is of particular interest at present. BF act in the recycling of nutrients between plant roots, microorganisms, and soils and are key components of integrated nutrient management [94].

Commercial rhizobia-based bioinoculants have existed for more than 100 years, and it is estimated that only $5 \%$ of the total fertilizer market includes BF, with about 150 microbe-based registered products available for use in agriculture $[95,96]$. There are several types of $B F$ including $N$ fixers and solubilizers of boron, $\mathrm{P}$, potash, sulfur, $\mathrm{Zn}$, among others [79]. N fixer BF are the most predominant in the market (78\%), followed by P solubilizer BF (15\%) [97]. Phytohormone-based BF are also used in agriculture as plant growth regulators [70]. Some examples of commercially available BF are Bio-N, Azonik, Green Earth Reap N4, Get-Phos, BioPotash, Siron, MicroZ-109, and BioSilica, which include strains of Azospirillum, Azotobacter, Rhizobium, Bacillus, and Thiobacillus and contribute to increased crop yields and soil fertility, showing their potential to be used in sustainable agriculture practices [98,99].

Crop yield can be improved up to $10 \%-40 \%$ with the inclusion of BF, mainly through increases in nutrient uptake [100].

The contribution of PGPB as BF is still very limited at a global level, and it is expected that in the near future the BF market will increase substantially to cope with population growth, the requirements of sustainable agricultural, consumer awareness of product residues, and the environmental impact of crop production. Furthermore, most of the research in this area is focused on rhizobacteria, and the role of endophytic bacteria is still little explored or understood.

\section{Iron Biofortification of Legumes with PGPB: A Case Study}

In the human diet, $\mathrm{Fe}$ is one of the most important micronutrients, being involved in the proper functioning of hemoglobin [31]. Human Fe deficiency is associated with cases of anemia, especially 
prevalent in pregnant women and preschool children. This micronutrient deficiency is the only one common to developing and developed economies [101].

In plants, Fe is an essential micronutrient required for multiple biological events, being the fourth most abundant element in the soil. It is required for photosynthesis, respiration, chlorophyll synthesis, and $\mathrm{N}$ fixation [102]. Ferric $\mathrm{Fe}\left(\mathrm{Fe}^{3+}\right)$, the form present in the soil, cannot be absorbed by plants, especially in calcareous soils with $\mathrm{pH}$ ranging from 7.5 to 8.5 [103,104]. Fe deficiency compromises the production of crops growing on alkaline soils around the world [102,105], and to mitigate this problem plants have evolved two strategies for Fe uptake. Strategy I, found in non-graminaceous monocots and dicots, is characterized by the release of protons, which results in the acidification of the rhizosphere, followed by the reduction of $\mathrm{Fe}^{3+}$ to $\mathrm{Fe}^{2+}$ through the activity of the ferric chelate reductase (FC-R) FRO2, and transportation to the root epidermal cells by the iron-regulated transporter 1 (IRT1) [102]. Strategy II, found in graminaceous monocots, is characterized by the production of phytosiderophores, which are responsible for Fe chelation, being the Fe-chelating complexes transported to the root epidermic cells [106].

In the Fe uptake process, there are specific low-molecular-weight organic compounds (1-2 kDa) produced by PGPB, under Fe-limiting conditions, called microbial siderophores [107]. They can bind $\mathrm{Fe}^{3+}$ at high specificity, increasing Fe solubility, and when this complex connects to specific bacterial receptors, Fe is more easily absorbed and converted to $\mathrm{Fe}^{2+}$ [108]. They are classified into three groups: hydroxamates, catecholates (phenolates), and carboxylates, according to the ligands that bind to $\mathrm{Fe}^{3+}$ [109]. It has been proposed that bacterial siderophores are involved in the promotion of Fe uptake by Strategy I plants (where legumes are included) through three different approaches: (1) sharing of ferric ions between microbial siderophores and plant FC-R, thus promoting Fe reduction and transport into the plant, (2) influence on the plant's perception of Fe deficiency conditions through the production of indole-acetic acid and ethylene, or (3) sequestration of the Fe required for the growth of phytopathogens [3,110-112]. Gram-positive and Gram-negative bacteria can produce siderophores under Fe deficiency $[113,114]$. These iron-chelating compounds are produced by several bacterial genera such as Agrobacterium, Bacillus, Burkholderia, Citrobacter, Enterobacter, Escherichia, Klebsiella, Pseudomonas, Rhizobium, and Stenotrophomonas [115].

As previously discussed, PGPB help in the uptake of several macro- and micronutrients, particularly of Fe. Few studies have shown the potential of legume biofortification regarding $\mathrm{Fe}$ uptake. Inoculation of chickpeas with siderophore-producer PGPB increased the Fe concentration by $81 \%$ and $75 \%$ in grains and shoots, respectively [116]. Also, in chickpeas, a study proved that inoculation with 19 Acinetobacter species increased overall seed nutrient content, with an increase of 10\%-38\% in Fe composition [117]. Also, pigeon peas and chickpeas treated with Enterobacter ludwigii SRI-229 and Pseudomonas monteilii SRI-360 had augmented nutrient composition and plant biomass; Fe content was increased up to $18 \%$ [87].

Both studies warn of the effects of postharvest processing and cooking on Fe concentration. Patel et al. [88] showed that the Fe content of mung beans could be improved 3.4-fold when inoculated with a Pantoea dispersa MPJ9 isolate. Biofortification of Fe using PGPB is a potential reality. Further studies are needed to assess the feasibility of using such types of bacteria at large scale and in field conditions. Efforts for Fe biofortification should also combine strategies to reduce the loss of Fe content during postharvest and processing.

\section{Conclusions}

Legumes are undoubtedly highly important targets to improve human nutrition while promoting sustainable agriculture. Biofortification of legumes with PGPB is potentially a cost-effective and environmentally safe approach to reduce dependency on chemical fertilizers and on costly biofortification techniques. We face an era where climate changes and increasing population are prevailing, and the combination of PGPB and legumes will most probably be a powerful tool to cope with hidden hunger and a trend for sustainable modern agriculture. Nonetheless, further investigation 
on which legumes, bacteria, and specific traits are needed and how they work under different soil compositions and environmental conditions is still essential. There are several studies regarding plant-microbe interactions and their important role in the environment; however, their transposition to agroecosystems and all their implications are still little explored. Furthermore, although the importance of legumes in providing essential nutrients is obvious, the lack of investigation limits the extent of their application in comparison with cereals.

Author Contributions: M.R. conceived and drafted the manuscript. S.M.P.C., P.M.L.C. and M.W.V. critically reviewed and helped to draft the manuscript. All authors have read and agreed to the published version of the manuscript.

Funding: This work was supported by the project TRansition paths to sUstainable legume-based systems in Europe (TRUE), which has received funding from the European Union's Horizon 2020 research and innovation program under grant agreement No. 727973.

Acknowledgments: We want to acknowledge the scientific support of FCT (Fundação para a Ciência e a Tecnologia) within the scope of UIDB/50016/2020, UIDB/05748/2020 and UIDP/05748/2020, and PhD scholarship SFRH/BD/109432/2015.

Conflicts of Interest: The authors declare no conflict of interest.

\section{References}

1. UNDESA. World Population Prospects: The 2012 Revision, United Nations Department of Economic and Social Affairs, New York. 2013. Available online: https://population.un.org/wpp/Publications/Files/ WPP2012_HIGHLIGHTS.pdf (accessed on 6 February 2019).

2. Jewell, M.C.; Campbell, B.C.; Godwin, I.D. Transgenic Plants for Abiotic Stress Resistance. In Transgenic Crop Plants; Springer: Berlin/Heidelberg, Germany, 2010.

3. Meena, V.S.; Meena, S.K.; Verma, J.P.; Kumar, A.; Aeron, A.; Mishra, P.K.; Bisht, J.K.; Pattanayak, A.; Naveed, M.; Dotaniya, M.L. Plant Beneficial Rhizospheric Microorganism (PBRM) Strategies to Improve Nutrients Use Efficiency: A Review. Ecol. Eng. 2017, 107, 8-32. [CrossRef]

4. Godfray HC, J.; Beddington, J.R.; Crute, I.R.; Haddad, L.; Lawrence, D.; Muir, J.F.; Pretty, J.; Robinson, S.; Thomas, S.M.; Toulmin, C. Food Security: The Challenge of Feeding 9 Billion People. Science 2010, 327, 812-818. [CrossRef]

5. Kumar, A.; Maurya, B.R.; Raghuwanshi, R.; Meena, V.S.; Tofazzal Islam, M. Co-Inoculation with Enterobacter and Rhizobacteria on Yield and Nutrient Uptake by Wheat (Triticum Aestivum L.) in the Alluvial Soil Under Indo-Gangetic Plain of India. J. Plant Growth Regul. 2017, 36, 608-617. [CrossRef]

6. Kumar, A.; Meena, V.S.; Maurya, B.R.; Raghuwanshi, R.; Bisht, J.K.; Pattanayak, A. Book Review. Appl. Soil Ecol. 2017, 117-118, 221-222. [CrossRef]

7. Nath, D.; Maurya, B.R.; Meena, V.S. Documentation of Five Potassium- and Phosphorus-Solubilizing Bacteria for Their K and P-Solubilization Ability from Various Minerals. Biocatal. Agric. Biotechnol. 2017, 10, 174-181. [CrossRef]

8. Finn, S. Nutrition Insecurity and Malnutrition in Developed Countries. In Addressing Malnutrition to Improve Global Health; Science/AAAS: Washington, DC, USA, 2014.

9. WHO. Biofortication of Staple Crops. Available online: http://www.who.int/elena/titles/biofortification/en/ (accessed on 23 September 2019).

10. White, P.J.; Broadley, M.R. Biofortification of Crops with Seven Mineral Elements Often Lacking in Human Diets - Iron, Zinc, Copper, Calcium, Magnesium, Selenium and Iodine. New Phytol. 2009, 182, 49-84. [CrossRef]

11. Carvalho, S.M.P.; Vasconcelos, M.W. Producing More with Less: Strategies and Novel Technologies for Plant-Based Food Biofortification. Food Res. Int. 2013, 54, 961-971. [CrossRef]

12. Golden Rice. Available online: http://www.goldenrice.org/ (accessed on 23 September 2019).

13. International Rice Research Institute. Available online: http://irri.org/golden-rice/faqs (accessed on 23 September 2019).

14. Garg, M.; Sharma, N.; Sharma, S.; Kapoor, P.; Kumar, A.; Chunduri, V.; Arora, P. Biofortified Crops Generated by Breeding, Agronomy, and Transgenic Approaches Are Improving Lives of Millions of People around the World. Front. Nutr. 2018, 5, 12. [CrossRef] 
15. Bouis, H.; Saltzman, A.; Birol, E. Improving Nutrition through Biofortification. In Agriculture for improved nutrition: Seizing the momentum; CAB International: Wallingford, UK, 2019.

16. Fuentes-Ramirez, L.E.; Caballero-Mellado, J. Bacterial Biofertilizers. In PGPR: Biocontrol and Biofertilization; Springer: Berlin/Heidelberg, Germany, 2005.

17. Ku, Y.S.; Rehman, H.M.; Lam, H.-M. Possible Roles of Rhizospheric and Endophytic Microbes to Provide a Safe and Affordable Means of Crop Biofortification. Agronomy 2019, 9, 764. [CrossRef]

18. Glick, B. Bacteria with ACC Deaminase Can Promote Plant Growth and Help to Feed the World. Microbiol. Res. 2014, 169, 30-39. [CrossRef]

19. Pereira, S.I.A.; Castro, P.M.L. Phosphate-Solubilizing Rhizobacteria Enhance Zea Mays Growth in Agricultural P-Deficient Soils. Ecol. Eng. 2014, 73, 526-535. [CrossRef]

20. Bahadur, I.; Maurya, B.R.; Kumar, A.; Meena, V.S.; Raghuwanshi, R. Towards the Soil Sustainability and Potassium-Solubilizing Microorganisms. In Potassium Solubilizing Microorganisms for Sustainable Agriculture; Springer India: New Delhi, India, 2016.

21. Etesami, H.; Beattie, G.A. Plant-Microbe Interactions in Adaptation of Agricultural Crops to Abiotic Stress Conditions. In Probiotics and Plant Health; Springer Singapore: Singapore, 2017.

22. İpek, M.; Eşitken, A. The Actions of PGPR on Micronutrient Availability in Soil and Plant Under Calcareous Soil Conditions: An Evaluation over Fe Nutrition. In Plant-Microbe Interactions in Agro-Ecological Perspectives; Springer Singapore: Singapore, 2017.

23. Karnwal, A. Isolation and Identification of Plant Growth Promoting Rhizobacteria from Maize (Zea Mays L.) Rhizosphere and Their Plant Growth Promoting Effect on Rice (Oryza Sativa L.). J. Plant Prot. Res. 2017, 57, 144-151. [CrossRef]

24. Moustaine, M.; Elkahkahi, R.; Benbouazza, A.; Benkirane, R.; EH, A. Effect of Plant Growth Promoting Rhizobacterial (PGPR) Inoculation on Growth in Tomato (Solanum Lycopersicum L.) and Characterization for Direct PGP Abilities in Morocco. Int. J. Environ. Agric. Biotechnol. 2017, 2, 590-596.

25. Sharifi, P. The Effect of Plant Growth Promoting Rhizobacteria (PGPR), Salicylic Acid and Drought Stress on Growth Indices, the Chlorophyll and Essential Oil of Hyssop (Hyssopus Officinalis). Biosci. Biotechnol. Res. Asia 2017, 14, 1033-1042. [CrossRef]

26. Kumari, M.; Gopal, A.; Lakshmipathy, R. Effect of Stress Tolerant Plant Growth Promoting Rhizobacteria on Growth of Blackgram under Stress Condition. Int. J. Curr. Microbiol. Appl. Sci. 2018, 7, 1479-1487. [CrossRef]

27. Soares, J.C.; Santos, C.S.; Carvalho SM, P.; Pintado, M.M.; Vasconcelos, M.W. Preserving the Nutritional Quality of Crop Plants under a Changing Climate: Importance and Strategies. Plant Soil 2019, 443, 1-26. [CrossRef]

28. Campbell, B.M.; Thornton, P.; Zougmoré, R.; van Asten, P.; Lipper, L. Sustainable Intensification: What Is Its Role in Climate Smart Agriculture? Curr. Opin. Environ. Sustain. 2014, 8, 39-43. [CrossRef]

29. Khan, A.; Singh, J.; Upadhayay, V.K.; Singh, A.V.; Shah, S. Microbial Biofortification: A Green Technology Through Plant Growth Promoting Microorganisms. In Sustainable Green Technologies for Environmental Management; Springer Singapore: Singapore, 2019.

30. United Nations. Sustainable Development Knowledge Platform. Available online: http://sustainabledevelopment. un.org/about (accessed on 21 September 2019).

31. Daly, D.H.; Velivelli, S.L.S.; Prestwich, B.D. The Role of Soil Microbes in Crop Biofortification. In Agriculturally Important Microbes for Sustainable Agriculture; Springer Singapore: Singapore, 2017.

32. Rehman, H.M.; Cooper, J.W.; Lam, H.-M.; Yang, S.H. Legume Biofortification Is an Underexploited Strategy for Combatting Hidden Hunger. Plant. Cell Environ. 2019, 42, 52-70. [CrossRef]

33. Jha, A.B.; Warkentin, T.D. Biofortification of Pulse Crops: Status and Future Perspectives. Plants 2020, 9, 73. [CrossRef]

34. Myers, S.S.; Zanobetti, A.; Kloog, I.; Huybers, P.; Leakey, A.D.B.; Bloom, A.J.; Carlisle, E.; Dietterich, L.H.; Fitzgerald, G.; Hasegawa, T.; et al. Increasing CO2 Threatens Human Nutrition. Nature 2014, 510, 139-142. [CrossRef]

35. Martín-Cabrejas, M. Legumes: Nutritional Quality, Processing and Potential Health Benefits. In Legumes and Their Associated Health Benefits; Royal Society of Chemistry: London, UK, 2019.

36. Ferreira, H.; Vasconcelos, M.; Gil, A.M.; Pinto, E. Benefits of Pulse Consumption on Metabolism and Health: A Systematic Review of Randomized Controlled Trials. Crit. Rev. Food Sci. Nutr. 2020, 1-12. [CrossRef] 
37. Karkanis, A.; Ntatsi, G.; Lepse, L.; Fernández, J.A.; Vågen, I.M.; Rewald, B.; Alsina, I.; Kronberga, A.; Balliu, A.; Olle, M.; et al. Faba Bean Cultivation—Revealing Novel Managing Practices for More Sustainable and Competitive European Cropping Systems. Front. Plant Sci. 2018, 9, 1115. [CrossRef]

38. Atienza, S.G.; Rubiales, D. Legumes in Sustainable Agriculture. Crop Pasture Sci. 2017, 68, i-ii. [CrossRef]

39. Ma, Y.; Schwenke, G.; Sun, L.; Liu, D.L.; Wang, B.; Yang, B. Modeling the Impact of Crop Rotation with Legume on Nitrous Oxide Emissions from Rain-Fed Agricultural Systems in Australia under Alternative Future Climate Scenarios. Sci. Total Environ. 2018, 630, 1544-1552. [CrossRef]

40. Vaz Patto, M.C.; Amarowicz, R.; Aryee AN, A.; Boye, J.I.; Chung, H.-J.; Martín-Cabrejas, M.A.; Domoney, C. Achievements and Challenges in Improving the Nutritional Quality of Food Legumes. CRC. Crit. Rev. Plant Sci. 2015, 34, 105-143. [CrossRef]

41. Herman, E.M.; Schmidt, M.A. The Potential for Engineering Enhanced Functional-Feed Soybeans for Sustainable Aquaculture Feed. Front. Plant Sci. 2016, 7, 440. [CrossRef]

42. Xu, J.G.; Tian, C.R.; Hu, Q.P.; Luo, J.Y.; Wang, X.D.; Tian, X.D. Dynamic Changes in Phenolic Compounds and Antioxidant Activity in Oats ( Avena Nuda L.) during Steeping and Germination. J. Agric. Food Chem. 2009, 57, 10392-10398. [CrossRef]

43. Tajaddini, A.; Pourzand, A.; Sanaat, Z.; Pirouzpanah, S. Dietary Resistant Starch Contained Foods and Breast Cancer Risk: A Case-Control Study in Northwest of Iran. Asian Pac. J. Cancer Prev. 2015, 16, 4185-4192. [CrossRef]

44. Zhu, B.; Sun, Y.; Qi, L.; Zhong, R.; Miao, X. Dietary Legume Consumption Reduces Risk of Colorectal Cancer: Evidence from a Meta-Analysis of Cohort Studies. Sci. Rep. 2015, 5, 8797. [CrossRef]

45. Li, J.; Mao, Q.-Q. Legume Intake and Risk of Prostate Cancer: A Meta-Analysis of Prospective Cohort Studies. Oncotarget 2017, 8, 44776-44784. [CrossRef]

46. Nderitu, A.M.; Dykes, L.; Awika, J.M.; Minnaar, A.; Duodu, K.G. Phenolic Composition and Inhibitory Effect against Oxidative DNA Damage of Cooked Cowpeas as Affected by Simulated in Vitro Gastrointestinal Digestion. Food Chem. 2013, 141, 1763-1771. [CrossRef] [PubMed]

47. Papanikolaou, Y.; Fulgoni, V.L. Bean Consumption Is Associated with Greater Nutrient Intake, Reduced Systolic Blood Pressure, Lower Body Weight, and a Smaller Waist Circumference in Adults: Results from the National Health and Nutrition Examination Survey 1999-2002. J. Am. Coll. Nutr. 2008, 27, 569-576. [CrossRef] [PubMed]

48. Ha, V.; Sievenpiper, J.L.; de Souza, R.J.; Jayalath, V.H.; Mirrahimi, A.; Agarwal, A.; Chiavaroli, L.; Mejia, S.B.; Sacks, F.M.; Di Buono, M.; et al. Effect of Dietary Pulse Intake on Established Therapeutic Lipid Targets for Cardiovascular Risk Reduction: A Systematic Review and Meta-Analysis of Randomized Controlled Trials. Can. Med. Assoc. J. 2014, 186, E252-E262. [CrossRef]

49. Rebello, C.J.; Greenway, F.L.; Finley, J.W. A Review of the Nutritional Value of Legumes and Their Effects on Obesity and Its Related Co-Morbidities. Obes. Rev. 2014, 15, 392-407. [CrossRef] [PubMed]

50. Miller, V.; Mente, A.; Dehghan, M.; Rangarajan, S.; Zhang, X.; Swaminathan, S.; Dagenais, G.; Gupta, R.; Mohan, V.; Lear, S.; et al. Fruit, Vegetable, and Legume Intake, and Cardiovascular Disease and Deaths in 18 Countries (PURE): A Prospective Cohort Study. Lancet 2017, 390, 2037-2049. [CrossRef]

51. Lopes, L.; Martins, M.; Farias, L.; Brito, A.; Lima, G.; Carvalho, V.; Pereira, C.; Conde Júnior, A.; Saldanha, T.; Arêas, J.; et al. Cholesterol-Lowering and Liver-Protective Effects of Cooked and Germinated Mung Beans (Vigna Radiata L.). Nutrients 2018, 10, 821. [CrossRef]

52. Yanai, H.; Tada, N. Effects of Intake of Soy and Non-Soy Legume on Serum HDL-Cholesterol Levels. J. Endocrinol. Metab. 2018, 8, 83-86. [CrossRef]

53. Singhal, P.; Kaushik, G.; Mathur, P. Antidiabetic Potential of Commonly Consumed Legumes: A Review. Crit. Rev. Food Sci. Nutr. 2014, 54, 655-672. [CrossRef]

54. Dhillon, P.K.; Bowen, L.; Kinra, S.; Bharathi, A.V.; Agrawal, S.; Prabhakaran, D.; Reddy, K.S.; Ebrahim, S. Legume Consumption and Its Association with Fasting Glucose, Insulin Resistance and Type 2 Diabetes in the Indian Migration Study. Public Health Nutr. 2016, 19, 3017-3026. [CrossRef]

55. Becerra-Tomás, N.; Díaz-López, A.; Rosique-Esteban, N.; Ros, E.; Buil-Cosiales, P.; Corella, D.; Estruch, R.; Fitó, M.; Serra-Majem, L.; Arós, F.; et al. Legume Consumption Is Inversely Associated with Type 2 Diabetes Incidence in Adults: A Prospective Assessment from the PREDIMED Study. Clin. Nutr. 2018, 37, 906-913. [CrossRef] 
56. Gebrelibanos, M.; Tesfaye, D.; Raghavendra, Y.; Sintayeyu, B. Nutritional and Health Implications of Legumes. Int. J. Pharm. Sci. Res. 2013, 4, 1269-1279.

57. Opie, R.S.; Itsiopoulos, C.; Parletta, N.; Sanchez-Villegas, A.; Akbaraly, T.N.; Ruusunen, A.; Jacka, F.N. Dietary Recommendations for the Prevention of Depression. Nutr. Neurosci. 2017, 20, 161-171. [CrossRef] [PubMed]

58. Zhong, X.; Ge, J.; Chen, S.; Xiong, Y.; Ma, S.; Chen, Q. Association between Dietary Isoflavones in Soy and Legumes and Endometrial Cancer: A Systematic Review and Meta-Analysis. J. Acad. Nutr. Diet. 2018, 118, 637-651. [CrossRef]

59. Gómez de Cedrón, M.; Ramírez de Molina, A.; Reglero, G. Legumes and Cancer. Available online: https: //www.glnc.org.au/legumes-2/legumes-and-health/legumes-and-cancer/ (accessed on 9 December 2019).

60. Ghosh, A.; Hasim Reja, M.; Nalia, A.; Kanthal, S.; Maji, S.; Venugopalan, V.K.; Nath, R. Micronutrient Biofortification in Pulses: An Agricultural Approach. Curr. J. Appl. Sci. Technol. 2019, 35, 1-12. [CrossRef]

61. Foyer, C.H.; Nguyen, H.; Lam, H.-M. Legumes-The Art and Science of Environmentally Sustainable Agriculture. Plant. Cell Environ. 2019, 42, 1-5. [CrossRef]

62. Zamioudis, C.; Pieterse, C.M.J. Modulation of Host Immunity by Beneficial Microbes. Mol. Plant Microbe Interact. 2012, 25, 139-150. [CrossRef]

63. Sattiraju, K.S.; Kotiyal, S.; Arora, A.; Maheshwari, M. Plant Growth-Promoting Microbes: Contribution to Stress Management in Plant Hosts. In Environmental Biotechnology: For Sustainable Future; Springer Singapore: Singapore, 2019.

64. Glick, B.R. Plant Growth-Promoting Bacteria: Mechanisms and Applications. Scientifica 2012, 2012 , 1-15. [CrossRef]

65. Islam, M.R.; Sultana, T.; Joe, M.M.; Yim, W.; Cho, J.-C.; Sa, T. Nitrogen-Fixing Bacteria with Multiple Plant Growth-Promoting Activities Enhance Growth of Tomato and Red Pepper. J. Basic Microbiol. 2013, 53, 1004-1015. [CrossRef]

66. Rodríguez, H.; Fraga, R.; Gonzalez, T.; Bashan, Y. Genetics of Phosphate Solubilization and Its Potential Applications for Improving Plant Growth-Promoting Bacteria. In First International Meeting on Microbial Phosphate Solubilization; Springer Netherlands: Dordrecht, The Netherlands, 2007.

67. Delvasto, P.; Ballester, A.; Muñoz, J.A.; González, F.; Blázquez, M.L.; Igual, J.M.; Valverde, A.; García-Balboa, C. Mobilization of Phosphorus from Iron Ore by the Bacterium Burkholderia Caribensis FeGL03. Miner. Eng. 2009, 22, 1-9. [CrossRef]

68. Glick, B.R.; Karaturovíc, D.M.; Newell, P.C. A Novel Procedure for Rapid Isolation of Plant Growth Promoting Pseudomonads. Can. J. Microbiol. 1995, 41, 533-536. [CrossRef]

69. Vacheron, J.; Desbrosses, G.; Bouffaud, M.-L.; Touraine, B.; Moënne-Loccoz, Y.; Muller, D.; Legendre, L.; Wisniewski-Dyé, F.; Prigent-Combaret, C. Plant Growth-Promoting Rhizobacteria and Root System Functioning. Front. Plant Sci. 2013, 4, 356. [CrossRef]

70. Maheshwari, D.K.; Dheeman, S.; Agarwal, M. Phytohormone-Producing PGPR for Sustainable Agriculture. In Bacterial Metabolites in Sustainable Development and Biodiversity; Springer: Cham, Switzerland, 2015.

71. Sayyed, R.; Badgujar, M.; Sonawane, H.; Mhaske, M.; Chincholkar, S. Production of Microbial Iron Chelators (Siderophores) by Fluorescent Pseudomonads. Indian J. Biotechnol. 2005, 4, 484-490.

72. Ahemad, M.; Kibret, M. Mechanisms and Applications of Plant Growth Promoting Rhizobacteria: Current Perspective. J. King Saud Univ. Sci. 2014, 26, 1-20. [CrossRef]

73. Beneduzi, A.; Ambrosini, A.; Passaglia, L. Plant Growth-Promoting Rhizobacteria (PGPR): Their Potential as Antagonists and Biocontrol Agents. Genet. Mol. Biol. 2012, 35, 1044-1051. [CrossRef] [PubMed]

74. Elshahat, M.R.; Ahmed, A.A.; Enas, A.H.; Fekria, M.S. Plant Growth Promoting Rhizobacteria and Their Potential for Biocontrol of Phytopathogens. Afr. J. Microbiol. Res. 2016, 10, 486-504. [CrossRef]

75. Premachandra, D.; Hudek, L.; Brau, L. Bacterial Modes of Action for Enhancing of Plant Growth. J. Biotechnol. Biomater. 2016, 6, 236.

76. Rosier, A.; Medeiros, F.H.V.; Bais, H.P. Defining Plant Growth Promoting Rhizobacteria Molecular and Biochemical Networks in Beneficial Plant-Microbe Interactions. Plant Soil 2018, 428, 35-55. [CrossRef]

77. Benidire, L.; Pereira, S.I.A.; Castro, P.M.L.; Boularbah, A. Assessment of Plant Growth Promoting Bacterial Populations in the Rhizosphere of Metallophytes from the Kettara Mine, Marrakech. Environ. Sci. Pollut. Res. 2016, 23, 21751-21765. [CrossRef] 
78. Moreira, H.; Pereira, S.I.A.; Marques, A.P.G.C.; Rangel, A.O.S.S.; Castro, P.M.L. Mine Land Valorization through Energy Maize Production Enhanced by the Application of Plant Growth-Promoting Rhizobacteria and Arbuscular Mycorrhizal Fungi. Environ. Sci. Pollut. Res. 2016, 23, 6940-6950. [CrossRef]

79. Verma, M.; Mishra, J.; Arora, N. Plant Growth-Promoting Rhizobacteria: Diversity and Applications. In Environmental Biotechnology: For Sustainable Future; Springer Singapore: Singapore, 2019.

80. Malusá, E.; Vassilev, N. A Contribution to Set a Legal Framework for Biofertilisers. Appl. Microbiol. Biotechnol. 2014, 98, 6599-6607. [CrossRef]

81. Rajkumar, M.; Ae, N.; Prasad, M.N.V.; Freitas, H. Potential of Siderophore-Producing Bacteria for Improving Heavy Metal Phytoextraction. Trends Biotechnol. 2010, 28, 142-149. [CrossRef]

82. Egamberdieva, D.; Berg, G.; Lindström, K.; Räsänen, L.A. Co-Inoculation of Pseudomonas Spp. with Rhizobium Improves Growth and Symbiotic Performance of Fodder Galega (Galega Orientalis Lam.). Eur. J. Soil Biol. 2010, 46, 269-272. [CrossRef]

83. Mishra, P.K.; Bisht, S.C.; Ruwari, P.; Joshi, G.K.; Singh, G.; Bisht, J.K.; Bhatt, J.C. Bioassociative Effect of Cold Tolerant Pseudomonas Spp. and Rhizobium Leguminosarum-PR1 on Iron Acquisition, Nutrient Uptake and Growth of Lentil (Lens Culinaris L.). Eur. J. Soil Biol. 2011, 47, 35-43. [CrossRef]

84. Mishra, P.K.; Bisht, S.C.; Mishra, S.; Selvakumar, G.; Bisht, J.K.; Gupta, H.S. Coinoculation of Rhizobium Leguminosarum-PR1 with a Cold Tolerant Pseudomonas Sp. Improves Iron Acquisition, Nutrient Uptake and Growth of Field Pea (Pisum Sativum L.). J. Plant Nutr. 2012, 35, 243-256. [CrossRef]

85. Stajkovic, O.; Delic, D.; Josic, D.; Kuzmanovic, D.; Rasulic, N.; Knezevic-Vukcevic, J. Improvement of Common Bean Growth by Co-Inoculation with Rhizobium and Plant Growth-Promoting Bacteria. Rom. Biotechnol. Lett. 2011, 16, 5919-5926.

86. Ramesh, A.; Sharma, S.K.; Sharma, M.P.; Yadav, N.; Joshi, O.P. Inoculation of Zinc Solubilizing Bacillus Aryabhattai Strains for Improved Growth, Mobilization and Biofortification of Zinc in Soybean and Wheat Cultivated in Vertisols of Central India. Appl. Soil Ecol. 2014, 73, 87-96. [CrossRef]

87. Gopalakrishnan, S.; Vadlamudi, S.; Samineni, S.; Sameer Kumar, C.V. Plant Growth-Promotion and Biofortification of Chickpea and Pigeonpea through Inoculation of Biocontrol Potential Bacteria, Isolated from Organic Soils. Springerplus 2016, 5, 1882. [CrossRef] [PubMed]

88. Patel, P.; Trivedi, G.; Saraf, M. Iron Biofortification in Mungbean Using Siderophore Producing Plant Growth Promoting Bacteria. Environ. Sustain. 2018, 1, 357-365. [CrossRef]

89. Htwe, A.Z.; Moh, S.M.; Moe, K.; Yamakawa, T. Effects of Co-Inoculation of Bradyrhizobium Japonicum SAY3-7 and Streptomyces Griseoflavus P4 on Plant Growth, Nodulation, Nitrogen Fixation, Nutrient Uptake, and Yield of Soybean in a Field Condition. Soil Sci. Plant Nutr. 2018, 64, 222-229. [CrossRef]

90. Ullah, A.; Farooq, M.; Hussain, M. Improving the Productivity, Profitability and Grain Quality of Kabuli Chickpea with Co-Application of Zinc and Endophyte Bacteria Enterobacter Sp. MN17. Arch. Agron. Soil Sci. 2019, 1-16. [CrossRef]

91. Ahmad, M.; Adil, Z.; Hussain, A.; Mumtaz, M.; Nafees, M.; Ahmad, I.; Jamil, M. Potential of Phosphate Solubilizing Bacillus Strains for Improving Growth and Nutrient Uptake in Mungbean and Maize Crops. Pak. J. Agric. Sci. 2019, 56, 283-289.

92. Dogra, N.; Yadav, R.; Kaur, M.; Adhikary, A.; Kumar, S.; Ramakrishna, W. Nutrient Enhancement of Chickpea Grown with Plant Growth Promoting Bacteria in Local Soil of Bathinda, Northwestern India. Physiol. Mol. Biol. Plants 2019, 25, 1251-1259. [CrossRef] [PubMed]

93. du Jardin, P. Plant Biostimulants: Definition, Concept, Main Categories and Regulation. Sci. Hortic. 2015, 196, 3-14. [CrossRef]

94. Vejan, P.; Abdullah, R.; Khadiran, T.; Ismail, S.; Nasrulhaq Boyce, A. Role of Plant Growth Promoting Rhizobacteria in Agricultural Sustainability-A Review. Molecules 2016, 21, 573. [CrossRef] [PubMed]

95. BCC Research. Biopesticides: The Global Market. Available online: https://www.mordorintelligence.com/ industry-reports/global-biopesticides-market-industry (accessed on 6 February 2019).

96. Arora, N.K.; Verma, M.; Mishra, J. Rhizobial Bioformulations: Past, Present and Future. In Rhizotrophs: Plant Growth Promotion to Bioremediation; Springer Singapore: Singapore, 2017.

97. Mishra, P.; Das, D. Rejuvenation of Biofertilizer for Sustainable Agriculture and Economic Development. Cons. J Sustain. Dev. 2014, 11, 41-61.

98. García-Fraile, P.; Menéndez, E.; Rivas, R. Role of Bacterial Biofertilizers in Agriculture and Forestry. AIMS Bioeng. 2015, 2, 183-205. [CrossRef] 
99. Thomas, L.; Singh, I. Microbial Biofertilizers: Types and Applications. In Biofertilizers for Sustainable Agriculture and Environment; Springer: Cham, Switzerland, 2019.

100. Bhardwaj, D.; Ansari, M.; Sahoo, R.; Tuteja, N. Biofertilizers Function as Key Player in Sustainable Agriculture by Improving Soil Fertility, Plant Tolerance and Crop Productivity. Microb. Cell Fact. 2014, 13, 66. [CrossRef]

101. WHO. Micronutrient Deficiencies: Iron Deficiency Anaemia. Available online: https://www.nhs.uk/ conditions/iron-deficiency-anaemia/ (accessed on 24 September 2019).

102. Marschner, P. Marschner's Mineral Nutrition of Higher Plants; Elsevier: Amsterdam, The Netherlands, 2012.

103. del Campillo, M.C.; Torrent, J. Predicting the Incidence of Iron Chlorosis in Calcareous Soils of Southern Spain. Commun. Soil Sci. Plant Anal. 1992, 23, 399-416. [CrossRef]

104. Miethke, M.; Marahiel, M.A. Siderophore-Based Iron Acquisition and Pathogen Control. Microbiol. Mol. Biol. Rev. 2007, 71, 413-451. [CrossRef]

105. Li, M.; Ahammed, G.J.; Li, C.; Bao, X.; Yu, J.; Huang, C.; Yin, H.; Zhou, J. Brassinosteroid Ameliorates Zinc Oxide Nanoparticles-Induced Oxidative Stress by Improving Antioxidant Potential and Redox Homeostasis in Tomato Seedling. Front. Plant Sci. 2016, 7, 615. [CrossRef]

106. Gendre, D.; Czernic, P.; Conéjéro, G.; Pianelli, K.; Briat, J.-F.; Lebrun, M.; Mari, S. TcYSL3, a Member of the YSL Gene Family from the Hyper-Accumulator Thlaspi Caerulescens, Encodes a Nicotianamine-Ni/Fe Transporter. Plant J. 2006, 49, 1-15. [CrossRef] [PubMed]

107. Payne, S.M. Detection, Isolation, and Characterization of Siderophores. Methods Enzymol. 1994, 235, 329-344.

108. Boukhalfa, H.; Crumbliss, A.L. Chemical Aspects of Siderophore Mediated Iron Transport. Biometals 2002, 15, 325-339. [CrossRef] [PubMed]

109. Hider, R.C.; Kong, X. Chemistry and Biology of Siderophores. Nat. Prod. Rep. 2010, 27, 637. [CrossRef] [PubMed]

110. Crowley, D.E.; Reid, C.P.P.; Szaniszlo, P.J. Utilization of Microbial Siderophores in Iron Acquisition by Oat. Plant Physiol. 1988, 87, 680-685. [CrossRef]

111. Lucena, C.; Waters, B.M.; Romera, F.J.; Garcia, M.J.; Morales, M.; Alcantara, E.; Perez-Vicente, R. Ethylene Could Influence Ferric Reductase, Iron Transporter, and H+-ATPase Gene Expression by Affecting FER (or FER-like) Gene Activity. J. Exp. Bot. 2006, 57, 4145-4154. [CrossRef]

112. Bacaicoa, E.; Mora, V.; Zamarreño, Á.M.; Fuentes, M.; Casanova, E.; García-Mina, J.M. Auxin: A Major Player in the Shoot-to-Root Regulation of Root Fe-Stress Physiological Responses to Fe Deficiency in Cucumber Plants. Plant Physiol. Biochem. 2011, 49, 545-556. [CrossRef]

113. Tian, F.; Ding, Y.; Zhu, H.; Yao, L.; Du, B. Genetic Diversity of Siderophore-Producing Bacteria of Tobacco Rhizosphere. Braz. J. Microbiol. 2009, 40, 276-284. [CrossRef]

114. Saharan, B.; Nehra, V. Plant Growth Promoting Rhizobacteria: A Critical Review. Life Sci. Med. Res. 2011, 2011, LSMR-21.

115. Esitken, A. Use of Plant Growth Promoting Rhizobacteria in Horticultural Crops. In Bacteria in Agrobiology: Crop Ecosystems; Springer: Berlin/Heidelberg, Germany, 2011.

116. Khalid, S.; Asghar, H.; Akhtar, M.; Aslam, A.; Zahir, Z. Biofortification of Iron in Chickpea by Plant Growth Promoting Rhizobacteria. Pak. J. Bot. 2015, 47, 1191-1194.

117. Sathya, A.; Vijayabharathi, R.; Srinivas, V.; Gopalakrishnan, S. Plant Growth-Promoting Actinobacteria on Chickpea Seed Mineral Density: An Upcoming Complementary Tool for Sustainable Biofortification Strategy. 3 Biotech 2016, 6, 138. [CrossRef] [PubMed]

(C) 2020 by the authors. Licensee MDPI, Basel, Switzerland. This article is an open access article distributed under the terms and conditions of the Creative Commons Attribution (CC BY) license (http://creativecommons.org/licenses/by/4.0/). 